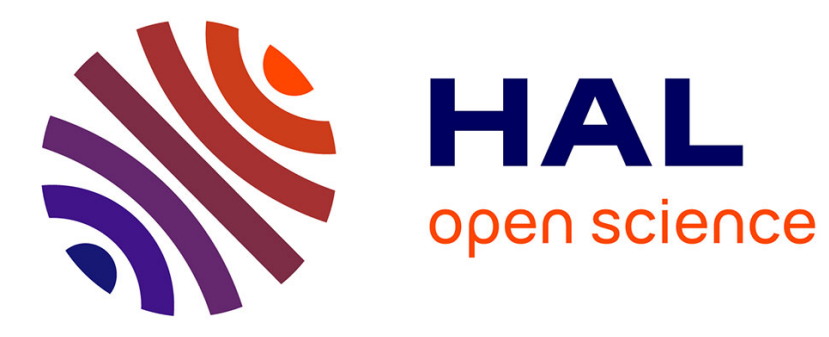

\title{
Dual switchable molecular tweezers incorporating anisotropic Mn-salphen complexes
}

Benjamin Doistau, Lorien Benda, Jean-Louis Cantin, Olivier Cador, Fabrice

Pointillart, Wolfgang Wernsdorfer, Lise-Marie Chamoreau, Valérie Marvaud, Bernold Hasenknopf, Guillaume Vives

\section{To cite this version:}

Benjamin Doistau, Lorien Benda, Jean-Louis Cantin, Olivier Cador, Fabrice Pointillart, et al.. Dual switchable molecular tweezers incorporating anisotropic Mn-salphen complexes. Dalton Transactions, 2020, 49 (26), pp.8872-8882. 10.1039/d0dt01465f . hal-02890145

\section{HAL Id: hal-02890145 \\ https://hal.science/hal-02890145}

Submitted on 4 Jan 2021

HAL is a multi-disciplinary open access archive for the deposit and dissemination of scientific research documents, whether they are published or not. The documents may come from teaching and research institutions in France or abroad, or from public or private research centers.
L'archive ouverte pluridisciplinaire HAL, est destinée au dépôt et à la diffusion de documents scientifiques de niveau recherche, publiés ou non, émanant des établissements d'enseignement et de recherche français ou étrangers, des laboratoires publics ou privés. 
Received 00th January 20xx, Accepted 00th January $20 x x$

DOI: $10.1039 / x 0 x \times 00000 x$

\title{
Dual Switchable Molecular Tweezers Incorporating Anisotropic Mn'"-Salphen Complexes
}

\begin{abstract}
Benjamin Doistau, ${ }^{\ddagger a}$ Lorien Benda, ${ }^{\ddagger a}$ Jean-Louis Cantin, ${ }^{b}$ Olivier Cador, ${ }^{c}$ Fabrice Pointillart, ${ }^{c}$ Wolfgang Wernsdorfer, ${ }^{d}$ Lise-Marie Chamoreau, ${ }^{a}$ Valérie Marvaud, ${ }^{a}$ Bernold Hasenknopf ${ }^{a}$ and Guillaume Vives* ${ }^{a}$

A new strategy for the synthesis of terpyridine based switchable molecular tweezers has been developed to incorporate anisotropic $\mathrm{Mn}$ (III)-salphen complexes. The free ligand was synthetized using a building block strategy based on Sonogashira coupling reactions and was then selectively metalated with manganese in a last step. The tweezers conformation was switched from an open 'W' shaped form to a closed ' $U$ ' form by $\mathrm{Zn}$ (II) coordination to the terpyridine unit bringing the two Mn-salphen moieties in close spatial proximity as confirmed by X-ray crystallography. An alternate switching mechanism was observed by the intercalation of a bridging cyanide ligand between the two Mn-salphen moieties that resulted in the tweezers' closing. These dual orthogonal stimulus are attractive to achieve multiple control of the tweezers' mechanical motion. A crystallographic structure of unexpected partially oxidized closed tweezers was also obtained. One of the two Mn-salphen moieties has undergone a ligand-centered oxidation of the imino to an amido group allowing an intramolecular $\mathrm{Mn}-\mathrm{O}_{\text {amide }}-\mathrm{Mn}$ linkage. The magnetic properties of the manganese(III) dimers were investigated to evaluate the magnetic exchange interaction and analyze the single molecule magnet behavior.
\end{abstract}

\section{Introduction}

Inspired by Nature or their macroscopic analogues, chemists have developed a large variety of molecular machines ${ }^{1}$ since the pioneering work of J.-P. Sauvage, F. Stoddart and B. Feringa who were rewarded by the Nobel prize in chemistry in 2016. While molecular machines allow a fine control of the mechanical motion, exploiting their operation to modulate physical or chemical properties at the molecular level remains a challenge. ${ }^{2}$ Among the large variety of molecular machines developed such as molecular switches, ${ }^{3}$ shuttles, ${ }^{4}$ motors, ${ }^{5}$ or nanovehicles, ${ }^{6}$ switchable molecular tweezers ${ }^{7}$ are particularly interesting mechanical switches. Such systems exploit stimuliresponsive switching units to control the distance between functional units enabling reversible guest recognition. Thus, a multi-responsive system by orthogonal stimulus is potentially accessible due to (i) the switching stimulus that can be redox ${ }^{8}$,

${ }^{a}$ Sorbonne Université, UMR CNRS 8232, Institut Parisien de Chimie Moléculaire, 4 place Jussieu, 75005, Paris, France

E-mail: guillaume.vives@sorbonne-universite.fr

${ }^{b}$ Sorbonne Université, INSP, 4 place Jussieu, 75005, Paris, France.

${ }^{c}$ Institut des Sciences Chimiques de Rennes UMR 6226 CNRS - Université Rennes 1, 35042 Rennes, France

${ }^{d}$ Physikalisches Institut and Institute of Nanotechnology, Karlsruhe Institute of Technology 76131 Karlsruhe, Germany CNRS and Université Grenoble Alpes, Institut Néel, 38042 Grenoble, France

¥ These authors have contributed equally to the work.

Electronic Supplementary Information (ESI) available: the supplementary information contains ${ }^{1} \mathrm{H},{ }^{13} \mathrm{C}$ NMR, UV-Vis titration data. See DOI: $10.1039 /$ b000000x/ photochemical $^{9}$ or coordination driven $^{10}$ and (ii) the guest interaction.

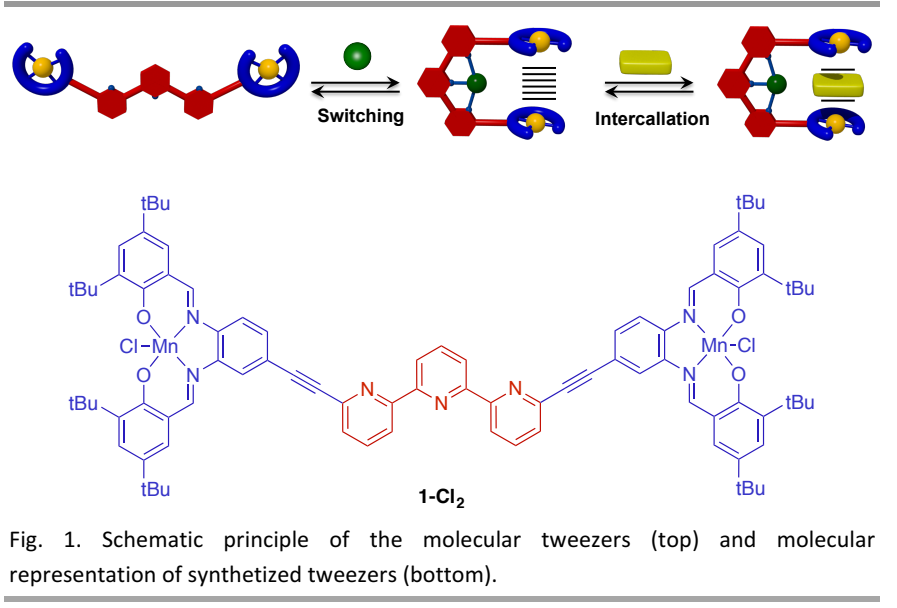

We have developed switchable molecular tweezers by metal coordination that present the advantage of stability and full conversion between the two states. Our system is composed of a terpyridine ligand substituted in 6 and $6 "$ positions by two arms bearing $\mathrm{M}$-salphen complexes as functional moieties (Fig. 1). Upon metal coordination the terpyridine can switch from a "W" shaped open form to a "U" shaped closed form, ${ }^{10 a-f}$ bringing the two functional units in close proximity. This controlled and large modification of the distance between the two functional units has been successfully applied to modulate luminescence, ${ }^{11}$ redox $^{12}$ or catalytic ${ }^{13}$ properties with $\mathrm{Pt}(\mathrm{II})$, 
$\mathrm{Ni}(\mathrm{II})$ and $\mathrm{Zn}$ (II) salphen complexes respectively. As a proof of concept with $\mathrm{Cu}$ (II) tweezers, we have obtained a switch from a paramagnetic to a weakly antiferromagnetically coupled system upon closing. ${ }^{14}$ Since this innovative approach to modulate magnetic properties remains largely unexplored, ${ }^{15}$ we wished, to incorporate $\mathrm{Mn}$ (III)-salphen complexes that present attractive magnetic properties. Indeed, $\mathrm{Mn}$ (III)-salen are versatile complexes that have been widely used in catalysis for oxidation ${ }^{16}$ or epoxidation ${ }^{17}$ reactions, as biomimetic models of manganese oxidase or catalase ${ }^{18}$ and extensively for their magnetic properties. ${ }^{19}$ In particular, the strong magnetic anisotropy of the $\mathrm{Mn}$ (III)-salen originating from the zero field splitting (ZFS) imposed by the Jahn-Teller elongation has attracted a large interest to generate Single Molecule Magnets (SMM) ${ }^{20}$ Such effect has been evidenced not only in $\mathrm{Mn}_{12}{ }^{21}$ and $\mathrm{Mn}_{6}{ }^{22}$ compounds but also in lower-nuclearity clusters, such as $\mathrm{Mn}$ (III) dimers that are of special interest. ${ }^{23}$ By modulating the magnetic properties of high spin ( $\mathrm{S}=2) \mathrm{Mn}(\mathrm{III})-$ salen complexes with the mechanical motion of the tweezers, we were interested in exploring two main aspects: (i) the potential additional intercalation of a bridging cyanide ligand to modulate the magnetic properties, (ii) a single molecule magnet behavior that might occur in $\mathrm{Mn}$ (III) dimers. Indeed, cyanide ligands have been widely used to obtain bridged polynuclear $\mathrm{Mn}$ complexes with controlled geometries and predictable exchange coupling interaction resulting in attractive magnetic properties. Herein the synthesis of the $\mathrm{Mn}$ based molecular tweezers as well as their switching and stimuli responsive magnetic properties are presented.

\section{Results and discussion}

\section{Synthesis}

Two routes were envisioned for the synthesis of tweezers 1- $\mathrm{Cl}_{\mathbf{2}}$ : (i) synthesis of the free ligand followed by a double coordination in the last step and (ii) "chemistry on complex" route where $\mathrm{Mn}$-salphen moieties are connected by a Sonogashira reaction to the terpyridine central unit. The latter approach avoids the challenge to coordinate selectively metal cations to the salphen and terpy parts but requires inert complexes as demonstrated with $\mathrm{Pt}(\mathrm{II}), \mathrm{Cu}(\mathrm{II})$ and $\mathrm{Ni}(\mathrm{II})$ analogues. Even if $\mathrm{Mn}(\mathrm{III})$-salphen complexes are more labile, this route was first investigated (Scheme 1). Free $\mathrm{Br}$-salphen ligand $2^{11 a}$ was coordinated to $\mathrm{MnCl}_{2}$ in presence of $\mathrm{Et}_{3} \mathrm{~N}$ to deprotonate the phenol groups and followed by air oxidation ${ }^{24}$

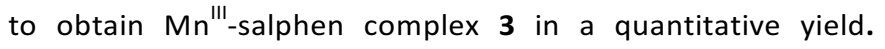
Complex $\mathbf{3}$ was further subjected to a Sonogashira coupling reaction with trimethylsilylacetylene (TMSA). High catalyst loading $\left(\mathrm{Pd}\left(\mathrm{PPh}_{3}\right)_{2} \mathrm{Cl}_{2} 15 \% \mathrm{~mol}, \mathrm{Cul} 30 \% \mathrm{~mol}\right)$ and excess of alkyne (10 equiv) were required for the reaction to proceed. The coupling product 4 was isolated after purification by column chromatography in a $59 \%$ yield. This indicates the compatibility of $\mathrm{Mn}$ (III)-salphen complexes with Sonogashira coupling conditions. The deprotection of the TMS group was attempted with $\mathrm{K}_{2} \mathrm{CO}_{3}$ in $\mathrm{MeOH} / \mathrm{THF}$, but a mixture of product with partial decoordination was obtained probability due to the formation of manganese hydroxide under the basic deprotection conditions. Alternative conditions using tetrabutylammonium fluoride (TBAF) were also attempted without success, leading only to the degradation of the complex.

In order to circumvent this problem, the coordination of the manganese on the alkyne substituted salphen ligand 7 was envisioned (Scheme 2). By a Sonogashira coupling of $\mathbf{2}$ with TMSA followed by deprotection, free salphen 7 was obtained. The yield of the Sonogashira coupling is moderate $(56 \%)$ due to a partial coordination of the product by the copper catalyst and hydrolysis of the imine bond during the purification by column chromatography. Coordination with $\mathrm{MnCl}_{2}$ yielded complex $\mathbf{5}$ in $71 \%$ yield. The final double Sonogashira coupling was then attempted using standard $\mathrm{PdCl}_{2}\left(\mathrm{PPh}_{3}\right)_{2}$ catalyst and more reactive electron-rich tri-tert-butyl phosphine $\left(\mathrm{PdCl}_{2}(\mathrm{PhCN})_{2},\left[(\mathrm{tBu})_{3} \mathrm{PH}\right] \mathrm{BF}_{4}\right)^{25}$ but in both cases only the Glaser homo-coupling product from two molecules of $\mathbf{5}$ was observed. The redox potential of $\mathrm{Mn}$ (III) being higher than that of $\mathrm{Cu}(\mathrm{I})$, a partial oxidation of $\mathrm{Cu}(\mathrm{I})$ to $\mathrm{Cu}(\mathrm{II})$ favoring Glaser coupling is probably the reason of this failure. Since it was difficult to use a large excess of alkyne like in the synthesis of salphen 4, the "chemistry on complex" synthetic strategy with $\mathrm{Mn}$-salphen coupling in the last step appeared not suitable for the incorporation of such sensitive complexes in the tweezers. An alternate route was designed introducing $\mathrm{Mn}$ (III) in an ultimate coordination step to metal-free tweezers ligand $\mathbf{9}$. Following this new route $\mathbf{7}$ was coupled to dibromoterpyridine 8 (Scheme 2). The free tweezers ligand 9 was obtained in 51\% yield after purification by column chromatography and recrystallization. In a last step, the manganese was coordinated to 9 using the usual conditions. An extraction with pentamethyldiethylenetriamine (PMDETA) was performed in order to remove excess manganese ions potentially coordinated to the terpyridine ligand. Due to the higher binding constant of the salphen moiety compared to the terpyridine tweezers $\mathbf{1}-\mathbf{C l}_{\mathbf{2}}$ was obtained in the open conformation with a $65 \%$ yield after a final recrystallization in

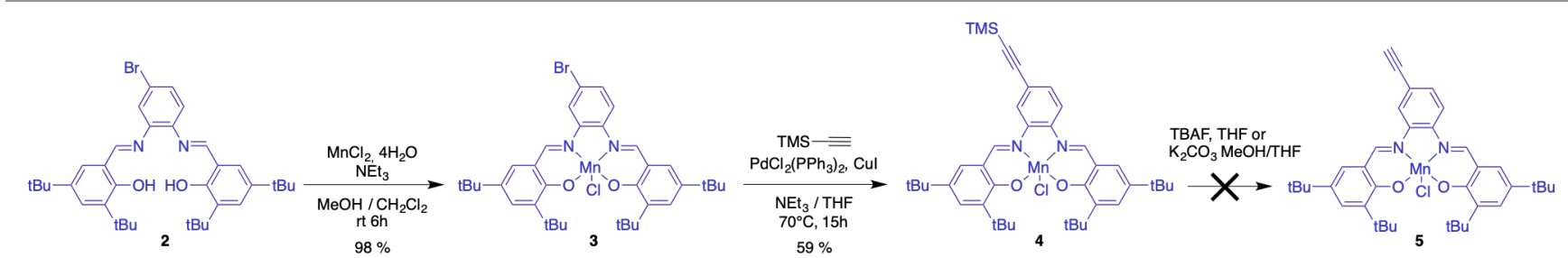

Scheme 1. First strategy based on a chemistry on complex with Mn-salphen. 


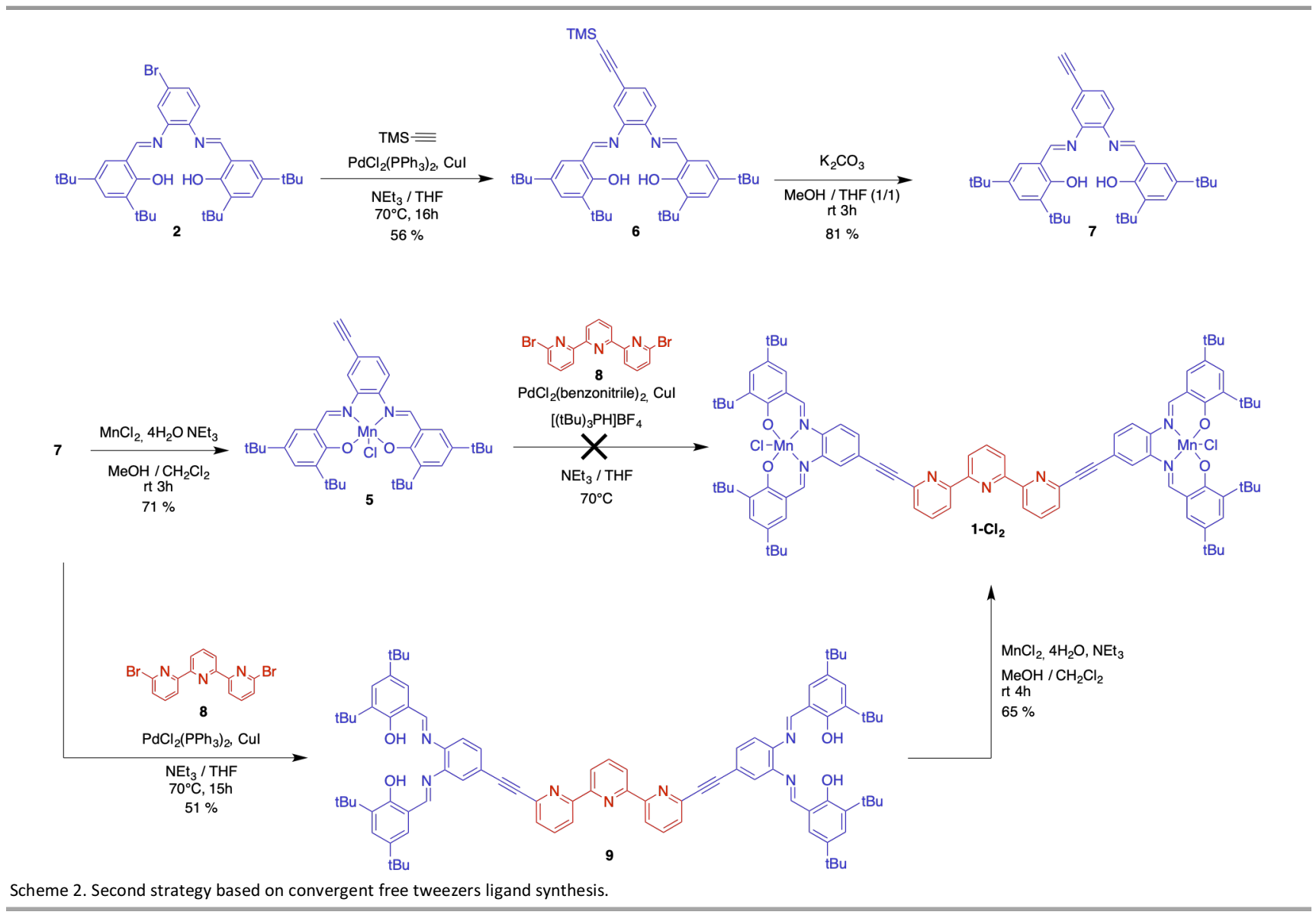

acetonitrile. HRMS spectrum is in agreement with an open conformation with signals at $\mathrm{m} / \mathrm{z} \quad 1499.62$ and 731.84 corresponding to $[\mathbf{1}-\mathrm{Cl}]^{+}$and $[\mathbf{1}]^{2+}$ respectively and no signal corresponding to a species with three $\mathrm{Mn}$ (III) ions (see Fig. S1). Thus, this new synthetic strategy opens up perspectives for the synthesis of tweezers incorporating complexes sensitive to cross-coupling reactions conditions, or labile first row transition metals. All the organic compounds have been fully characterized by ${ }^{1} \mathrm{H},{ }^{13} \mathrm{C}$ and $2 \mathrm{D} \mathrm{NMR}$ and mass spectrometry (ESI-HSMS). Full details are given in the experimental section and ESI.

\section{Switching studies by zinc coordination}

The closing of tweezers $\mathbf{1}-\mathbf{C l}_{\mathbf{2}}$ was monitored by UV-Vis spectroscopy in chloroform. Titration of $\mathbf{1}-\mathbf{C l}_{2}$ with $\mathrm{ZnCl}_{2}$ (Fig. 2) showed a single evolution up to 1.0 equiv of $\mathrm{Zn}^{2+}$ with isosbestic points at the two curve crossings $(\lambda=358$ and 485 $\mathrm{nm})$, which is consistent with an equilibrium solely between the open and closed forms. The formation of a 1:1 complex was confirmed by mass spectrometry with signals at $\mathrm{m} / \mathrm{z}$ 1634.49 corresponding to mono-cationic $\left[\mathrm{Zn}\left(\mathbf{1}-\mathrm{Cl}_{2}\right) \mathrm{Cl}^{+}\right.$and 799.72 di-cationic $\left[\mathrm{Zn}\left(\mathbf{1}-\mathrm{Cl}_{2}\right)\right]^{2+}$ complexes (see Fig. S2). Fitting of the titration curve with a 1:1 binding model revealed a strong association constant ( $\log K>7)$ comparable to previous terpy-based tweezers. ${ }^{11 a}$ When the titration was performed in methanol a similar behavior was observed with a single evolution leading to the formation of $\left[\mathrm{Zn}(\mathbf{1}) \mathrm{Cl}_{2}\right]$ (see Fig. S3).
However, the apparent binding constant is much lower ( $\log K=4.7$ ) due to the presence of methanol as competing coordinating solvent for the $\mathrm{Zn}(\mathrm{II})$.

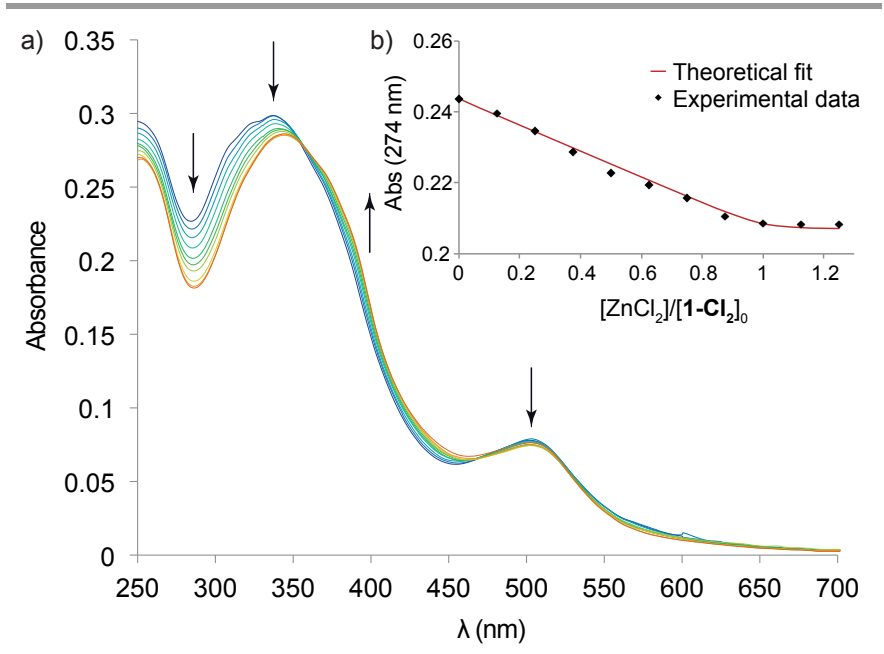

Fig. 2. a) UV-Vis titration of $1-\mathrm{Cl}_{2}\left(5.0 \times 10^{-6} \mathrm{~mol} \cdot \mathrm{L}^{-1}\right)$ by $\mathrm{ZnCl}_{2}$ in $\mathrm{CHCl}_{3}$. b) Absorption at $274 \mathrm{~nm}$ and fitting with a 1:1 binding model.

Single crystals of the closed tweezers suitable for X-ray diffraction were obtained by slow evaporation of a methanol solution (Fig. 3). $\left[\mathrm{Zn}\left(\mathbf{1}-\mathrm{Cl}_{\mathbf{2}}\right)\right] \mathrm{Cl}_{2}$ crystalize in a triclinic space group P-1 $\left(\mathrm{N}^{\circ} 2\right)$ with an unit cell of 5137. 24(13) $\AA^{3}$ $(a=14.1647(2) \quad \AA ; \quad b=15.3020(2) \quad \AA ; \quad c=25.9901(4) \AA$ $\left.\alpha=88.1420(10)^{\circ} ; \beta=84.2230(10)^{\circ} ; \gamma=66.4380(10)^{\circ}\right)$ bearing 
two molecules in a tight packing. The molecule adopts a helicoidal geometry with the two enantiomers present in the crystal. The alkyne spacers are distorted from linearity with angles of $174^{\circ}$ and $166^{\circ}$ to enable the two salphen moieties to point outward to avoid steric hindrance between the two pseudo-octahedral $\mathrm{Mn}$ ions resulting in a $\mathrm{Mn}-\mathrm{Mn}$ distance of $6.2 \AA$. Surprisingly the two $\mathrm{Mn}$-salphen complexes present a different coordination sphere for the $\mathrm{Mn}$, the first one adopts a distorted Jahn Teller octahedral geometry with average $\mathrm{Mn}$ $\mathrm{N}$ and $\mathrm{Mn}-\mathrm{O}$ distances of $1.98 \AA$ and $1.87 \AA$ respectively, a chloride ligand in apical position ( $\mathrm{Mn}-\mathrm{Cl}: 2.4827(8) \AA$ ) pointing inward the cavity and a methanol ligand (Mn-OMe : 2.508(3) Å) pointing to the outside. The second Mn ion adopts a pseudo-octahedral geometry less distorted with methanol and water ligands in apical positions (Mn-OMe:

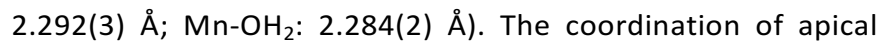
ligands on the manganese prevents their stacking and results in an open cavity despite the coordination of the zinc on the terpyridine ligand that forces the salphen moieties to be in proximity. The +III oxidation state for both $\mathrm{Mn}$ ions was confirmed by the presence of one chloride counter ion in the asymmetric unit.

a)

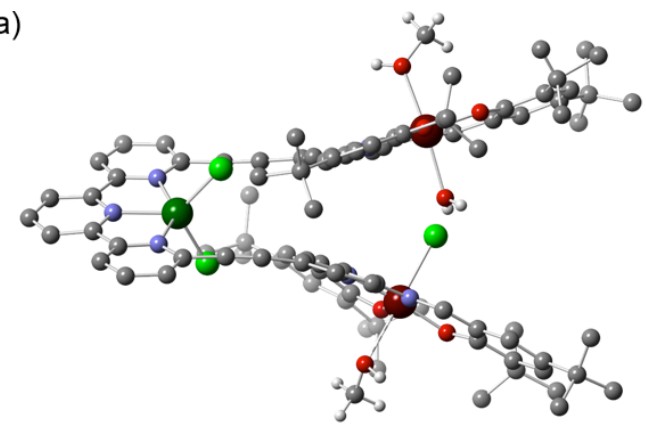

b)

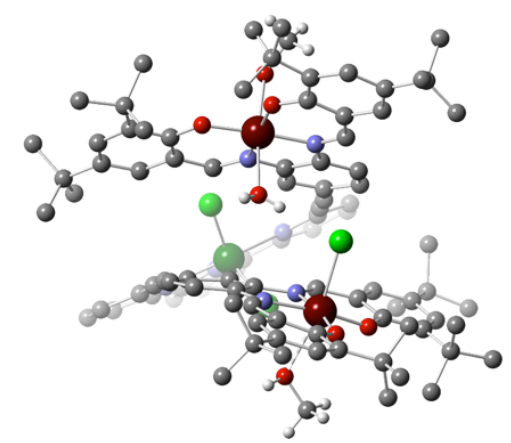

Fig. 3. Single crystal X-ray diffraction structure of $\left[\mathrm{Zn}\left(\mathbf{1}-\mathrm{Cl}_{2}\right)\right] \mathrm{Cl}_{2}$ a) side and b) front view; Solvent molecules, counter anions and hydrogen atoms (except on $\mathrm{H}_{2} \mathrm{O}$ and $\mathrm{CH}_{3} \mathrm{OH}$ ) are omitted for clarity.

The effect of the conformation change on the magnetic properties was first studied by EPR spectroscopy. High spin $\mathrm{Mn}(\mathrm{III})$ is an integer spin ( $\mathrm{S}=2$ ) system which is considered as EPR silent for standard perpendicular mode EPR spectroscopy. ${ }^{26}$ However parallel mode EPR can be used and a characteristic sextuplet was observed at low field for the open tweezers $1-\mathbf{C l}_{2}$ (Fig. 4a). Due to the large zero field splitting value (2.1 to $2.5 \mathrm{~cm}^{-1}$ for $\mathrm{Mn}(\mathrm{III})^{27}$ ) of the ground state, the transitions observed in X-band arise only from $\mathrm{M}_{\mathrm{S}}=-2 \rightarrow 2$ levels with an hyperfine coupling with the nuclear spin (I=5/2) of $\mathrm{Mn}$ as described in the literature. ${ }^{27}$ The spectrum was accurately simulated (Fig. 4) with $D=-2.5 \mathrm{~cm}^{-1}, E=0.046 \mathrm{~cm}^{-1}$, $\mathrm{A}_{\perp}=190 \mathrm{MHz}, \mathrm{A}_{/ /}=118 \mathrm{MHz}, \mathrm{g}_{\perp}=2.0$, and $\mathrm{g}_{/ /}=1.98$ parameters. Since the EPR simulation is not sensitive to the perpendicular $\mathrm{g}$ and $\mathrm{A}$ values, typical values for axially elongated six-coordinate $\mathrm{Mn}(\mathrm{III})$ ions were selected. Upon addition of $\mathrm{ZnCl}_{2}$ the signal is broadened (Fig. $4 \mathrm{~b}$ ) probably due to dipolar interactions between the two $\mathrm{Mn}(\mathrm{III})$ centers that are in spatial proximity in the closed conformation.

Since anisotropic $\mathrm{Mn}$ (III) complexes have been reported to display SMM behavior, the effect of the conformation change were further investigated by SQUID magnetometry. The alternating current (ac) magnetic susceptibilities were measured in frozen solution to avoid intermolecular interactions for different applied static fields. No out-of-phase component of the magnetic susceptibility was observed for the open and closed tweezers at any magnetic field indicating the absence of slow relaxation of the magnetization i.e. no SMM behavior. The lack of significant magnetic interactions between the two $\mathrm{Mn}$-salphen units in the closed state as expected from the large $\mathrm{Mn}-\mathrm{Mn}$ distance in solid state should be responsible for this absence of SMM behavior.

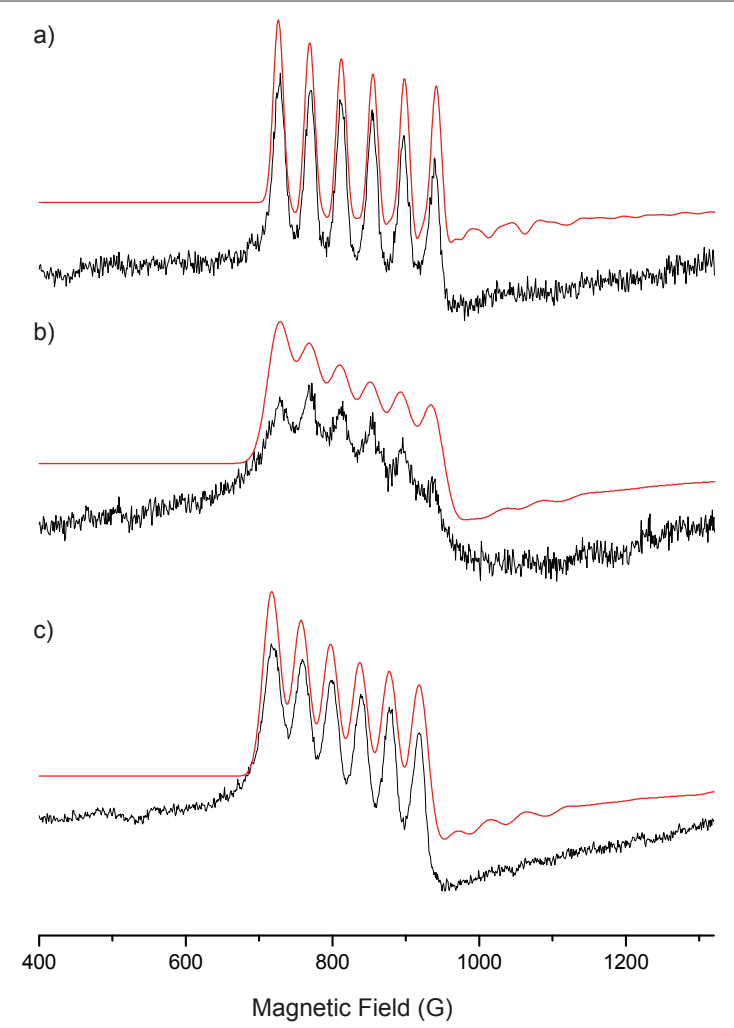

Fig. 4. X-band EPR spectra of a) open tweezers $\left.1-\mathrm{Cl}_{2}, \mathrm{~b}\right)$ closed tweezers $\left[\mathrm{Zn}\left(\mathbf{1}-\mathrm{Cl}_{2}\right) \mathrm{Cl}_{2}\right]$ and c) tweezers $1-\mathrm{Cl}_{2}$ with $\mathrm{CN}^{-}$(in $\mathrm{MeOH}$ at $5 \mathrm{~K}$ ) in parallel mode.

\section{Intercalation studies with cyanide ligand}

In order to increase the magnetic interaction between the two $\mathrm{Mn}$ (III) center in the closed form, the effect of a bridging ligand 
was investigated. Since cyanide bridged $\mathrm{Mn}$ (III)-salen complexes display attractive properties such as spin-crossover, photomagnetic or single molecule magnet behavior, ${ }^{19 d, 20}$ the binding of cyanide ligand to tweezers $\mathbf{1}-\mathbf{C l}_{\mathbf{2}}$ was explored by UV-Vis titration. Upon addition of tetrabutylammonium cyanide (TBACN) to a solution of open tweezers $\mathbf{1}-\mathbf{C l}_{\mathbf{2}}$ in chloroform a bathochromic shift was observed for the MLCT transition at $510 \mathrm{~nm}$ with a broader band appearing around $550 \mathrm{~nm}$ (Fig. 5). The transitions in the UV regions are also affected by the addition of cyanide ligand with a hypochromic shift. This behavior was also observed for model $\mathrm{Mn}$-salphen complex 10 (see Fig. S4) indicating the coordination of cyanide to the $\mathrm{Mn}$ (III) center. A single evolution with isosbestic points at all curve crossing $(\lambda=398,428$ and $540 \mathrm{~nm})$ was observed between 0 to around 1 equiv of $\mathrm{CN}^{-}$indicating a strong binding of one cyanide ligand to tweezers $1-\mathrm{Cl}_{2}(\log \mathrm{K}=7.2)$. In contrast, the titration with model $\mathrm{Mn}$-salphen presented a smooth evolution up to 4 equivalents corresponding to the successive coordination of two $C N$ ligands $\left(\log K_{1}=4.5 ; \log K_{2}=\right.$ 3.3) to form the $\left[\mathrm{Mn} \text {-salphen }(\mathrm{CN})_{2}\right]^{-}$complex as previously reported. ${ }^{28}$ This significant difference between tweezers $\mathbf{1}-\mathbf{C l}_{\mathbf{2}}$ and model $\mathrm{Mn}$-salphen complex is probably due to the formation of an intramolecular cyanide bridged $\mathrm{Mn}$ dimer that forces the tweezers closing instead of forming the expected open $\left[\mathbf{1}(\mathrm{CN})_{4}\right]^{2-}$ species. The infrared spectrum is in agreement with a bridging $\mathrm{CN}$ ligand as the observed v(CN) band at 2205 $\mathrm{cm}^{-1}$ for [1-CN] is shifted to higher energy compared to model $\left[\mathrm{Mn} \text {-salphen }(\mathrm{CN})_{2}\right]^{-}$at $2195 \mathrm{~cm}^{-1}$. Such increase in the $\mathrm{v}(\mathrm{CN})$ values is typical for bridged $\mathrm{M}-\mathrm{CN}-\mathrm{M}$ system compared with terminal $\mathrm{M}-\mathrm{CN}$ as the donation of $\sigma$-electron density from the antibonding lone pair on the nitrogen depopulates the antibonding $\mathrm{CN}$ orbital and strengthens the triple bond. ${ }^{29} \mathrm{EPR}$ spectroscopy provided further evidence on the cyanide binding mode. Upon addition of cyanide ligand to model Mnsalphen complex a disappearance of the characteristic sextuplet was observed in EPR (see Fig. S5) as expected for low $\operatorname{spin}(\mathrm{S}=1)$ EPR silent $\left[\mathrm{Mn} \text {-salphen }(\mathrm{CN})_{2}\right]^{-}$complex. $^{28} \mathrm{In}$ contrast, upon addition of $\mathrm{CN}^{-}$ligand to open tweezers $\mathbf{1 - \mathrm { Cl } _ { 2 }}$ an EPR signal is still observed with only a slight change in the hyperfine structure from $42.5 \mathrm{G}$ to $40 \mathrm{G}$ (Fig. 4c) indicating a modification in the coordination sphere of the $\mathrm{Mn}$ and a high spin (HS) Mn-salphen moiety. One HS $\mathrm{Mn}$ (III) is expected in case of an intramolecular $\mathrm{Mn}-\mathrm{CN}-\mathrm{Mn}$ bridge as the coordination by the nitrogen atom is not enough sigma donor to induce a spin transition of the $\mathrm{Mn}($ III) to a LS configuration. ${ }^{19 a}$ The formation of a mixed HS/LS configuration for the cyanide-closed tweezers was confirmed by magnetometry experiments performed in frozen solution (see Fig. S8). The high temperature $\chi^{\top}$ saturation value for the cyanide closed tweezers is lower than zinc closed tweezers $\left[\mathrm{Zn}\left(\mathbf{1}-\mathrm{Cl}_{\mathbf{2}}\right)\right] \mathrm{Cl}_{2}$ as expected from the resulting total spin system $S=3$ compared to $S=4$. AC magnetic susceptibilities were also measured in frozen solution, but no out-of-phase component of the magnetic susceptibility was observed at any magnetic field indicating no SMM behavior of this cyanide bridged $\mathrm{Mn}$ dimer. Nevertheless, cyanide ligand by bridging the two functional $\mathrm{Mn}$-salphen can be considered as an alternate stimulus to close the tweezers. This orthogonal mechanism compared to $\mathrm{Zn}$ (II) coordination to the terpy unit offers attractive perspectives to achieve multiple control of the tweezers' mechanical motion.

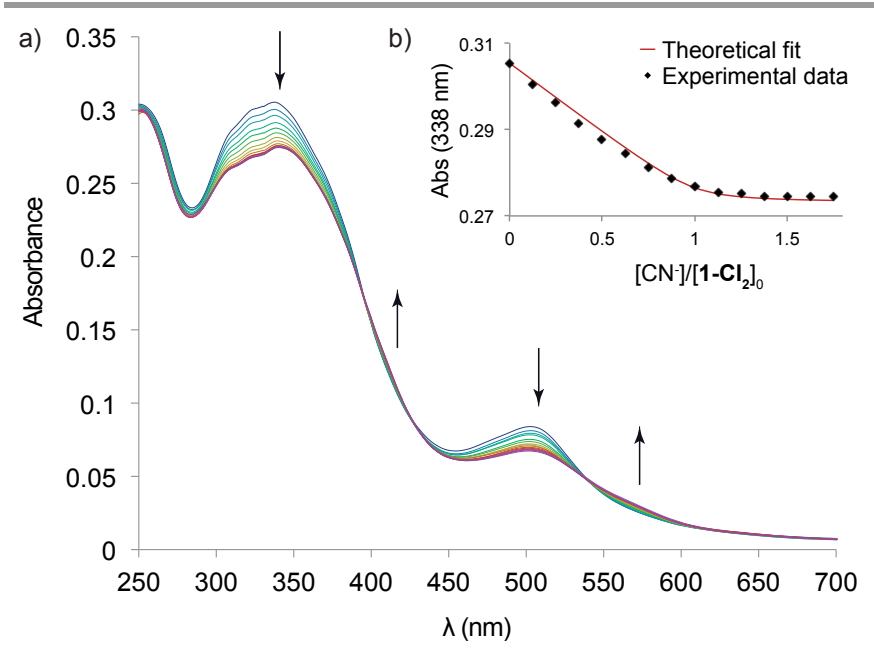

Fig. 5 UV-Vis titration of $1-\mathrm{Cl}_{2}\left(5.0 \times 10^{-6} \mathrm{~mol} \cdot \mathrm{L}^{-1}\right)$ by TBACN in $\mathrm{CHCl}_{3}$. b) Absorption at $338 \mathrm{~nm}$ and fitting with a 1:1 binding model.

The effect of the addition of cyanide ligand to the already zincclosed tweezers was also investigated. The UV-Vis titration in chloroform (see Fig. S6) presents a first evolution up to 2 equiv of $\mathrm{CN}$ that can be attributed to the exchange of the chloride ligands on the $\mathrm{Zn}(\mathrm{II})$ and a second evolution corresponding to the exchange of the chloride on the $\mathrm{Mn}$ (III) centers. Indeed, at the end of the titration upon addition of an excess of cyanide a $\left[\mathrm{Zn}(\mathbf{1})(\mathrm{CN})_{5}\right]^{-}$species was observed by mass spectrometry with a signal at $m / z 1659.6$ (see Fig. S9). This species corresponds to the exchange of the chloride ligands by cyanide on both $\mathrm{Zn}$ (II) and $\mathrm{Mn}(\mathrm{III})$ centers and the coordination of additional cyanide that should act as bridging ligand between the two $\mathrm{Mn}$ salphen moieties. Upon addition of cyanide to closed tweezers $\left[\mathrm{Zn}\left(\mathbf{1}-\mathrm{Cl}_{2}\right) \mathrm{Cl}_{2}\right]$ the EPR spectra display first a broadening and decrease of the signal intensity. Then upon addition of a large excess ( $\sim 50$ equiv) of cyanide a signal similar to the one obtained with open tweezers in presence of cyanide but with a lower intensity is observed (see Fig. S7) that might be explained by cyanide-induced zinc demetallation, as $\left[\mathrm{Zn}(\mathrm{CN})_{4}\right]^{2-}$ species was observed by mass spectrometry.

\section{Unexpected tweezers oxidation}

In an attempt to obtain a better insight into the structure of the tweezers with cyanide ions single crystals suitable for XRD were grown by slow evaporation of a solution of closed tweezers $\left[\mathrm{Zn}\left(\mathbf{1}-\mathrm{Cl}_{\mathbf{2}}\right)\right] \mathrm{Cl}_{2}$ in methanol with TBACN. The tweezers crystalize in the triclinic space group P-1 $\left(\mathrm{N}^{\circ} 2\right)$ with a unit cell of $5254.72 \AA^{3}(a=15.1358(12) \AA$; $b=16.521(1) \AA \AA ; c=$ $22.9401(16) \AA \AA \alpha=89.629(5)^{\circ} ; \beta=72.981(5)^{\circ} ; \gamma=73.972(5)^{\circ}$ ) (Fig. 6). 

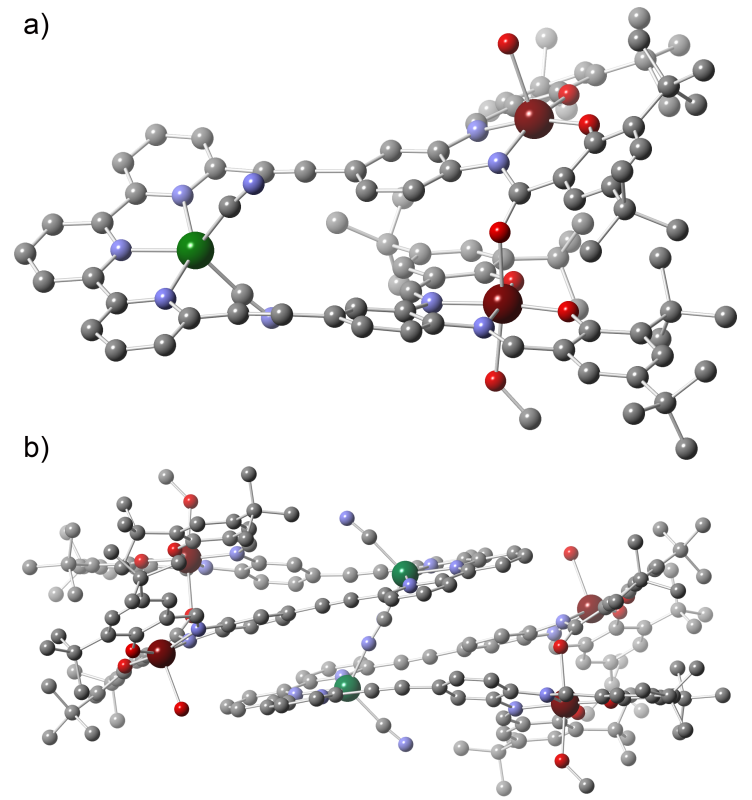

Fig. 6. Single crystal X-ray diffraction structure of oxidized closed tweezers with cyanide; a) side view b) packing showing the dimer with a cyanide bridging ligand. Solvent molecules and hydrogen atoms are omitted for clarity.

The cyanides ligands are not coordinated to manganese despite the ligand field stabilization effect of such ligands but to the zinc of the terpyridine unit. One cyanide acts a bridged between two tweezers by a $\mathrm{Zn}-\mathrm{CN}-\mathrm{Zn}$ linkage (with a disordered orientation of the $\mathrm{CN}^{-}$), the zinc coordination sphere being completed by a second terminal cyanide. The C-N distance of bridging cyanide (1.18(1) $\AA$ ) is slightly longer than for non-bridging one (1.12(1) $\AA$ ) highlighting the double electronic retro-donation of the zinc to the bridge. Interestingly one $\mathrm{Mn}$-salphen moiety of each tweezers has undergone a ligand localized oxidation of an imino to an amido group. The oxygen of the so-formed amido group is coordinated to the other $\mathrm{Mn}$ of the tweezers resulting in an intramolecular dimer with a Mn-Mn distance of $5.408 \AA$ much shorter than in $[\mathrm{Zn}(\mathbf{1})] \mathrm{Cl}_{2}$. While the oxidized $\mathrm{Mn}$-salphen displays a distorted pyramidal geometry with an hydroxyl in apical position ( $\mathrm{Mn}-\mathrm{OH}: 2.336(5) \AA ̊ \Omega)$, the non-oxidized Mn-salphen adopts a Jahn Teller distorted octahedral geometry with a methanol molecule in apical position (Mn-OMe : 2.274(7) $\AA$ ) and the amide oxygen of the oxidized $\mathrm{Mn}$-salphen completing the coordination sphere $\left(\mathrm{Mn}-\mathrm{O}_{\text {amide: }}\right.$ : 2.210(6) $\AA$ ). This type of selective ligand oxidation of monometallic $\mathrm{Mn}$-salphen complexes by dioxygen has already been described by Floriani as a self-catalyzed $\mathrm{Mn}$ oxidation with the intermediate formation of manganese dimers with the $\mathrm{Mn}-\mathrm{O}_{\text {amide }} \mathrm{Mn}$ linkage (Fig. 7). ${ }^{30}$ The ligand oxidation seems to be herein promoted by the spatial proximity of $\mathrm{Mn}$-salphen moieties in closed tweezers enabling room temperature air oxidation in methanol during the crystallization time. The formation of such oxidized tweezers species was also observed by mass spectrometry on a solution of tweezers in $\mathrm{MeOH}$ left standing for a few weeks with signals at $\mathrm{m} / z \quad 1479.6$ and 1596.6 corresponding to $\left[1^{\mathrm{Ox}}\right]^{+}$and $\left[\mathrm{Zn}\left(1^{\mathrm{Ox}}\right)(\mathrm{CN})_{2}\right]^{+}$respectively (see Fig. S10). Thus, the intramolecular linkage between Mnsalphen moieties corroborates the oxidized product obtained by Floriani involving manganese salen dimers.

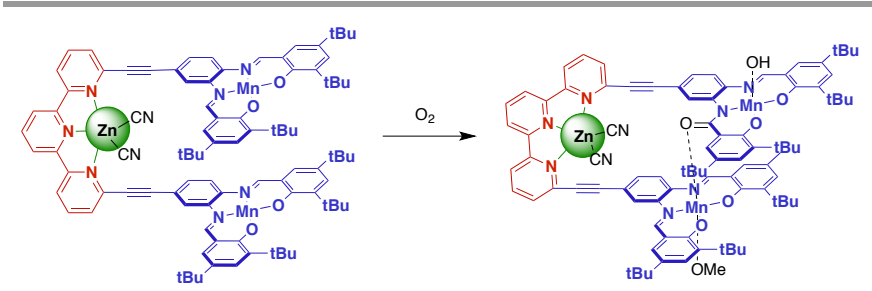

Fig. 7. Schematic representation of the ligand oxidation to form a manganese dimer.

Preliminary Micro-SQUID experiments were performed on single crystals of the zinc-closed oxidized tweezers. At low temperature the sample displayed little magnetic response up to $1.4 \mathrm{~T}$ indicative of a $\mathrm{S}=0$ ground state due to an antiferromagnetic exchange interaction between the two $\mathrm{Mn}$ centers. Even if this low spin ground state precludes any SMM behavior, the mechanical motion of the tweezers' closing enabled a switch from a paramagnetic high spin system to a low spin antiferromagnetically coupled one.

\section{Conclusion}

An alternative to the "chemistry on complex" strategy was successfully conducted for the synthesis of manganese based molecular tweezers, thus enabling the incorporation of labile cations, not compatible with post-functionalization steps, in such switchable tweezers. The closing mechanical motion of the tweezers was achieved by the coordination of $\mathrm{Zn}$ (II) to the terpyridine unit bringing in spatial proximity the two $\mathrm{Mn}$ salphen units as shown by XRD or EPR. Interestingly, the binding of a cyanide guest ligand to the $\mathrm{Mn}$-salphen units also resulted in the closing of the tweezers via an intramolecular $\mathrm{Mn}-\mathrm{CN}-\mathrm{Mn}$ bridge. This bridge is stable enough to trigger the closing without $\mathrm{Zn}$-coordination to the terpyridine unit offering an orthogonal closing stimulus and attractive perspectives to achieve multiple control of the mechanical motion of the tweezers. The magnetic properties of the closed tweezers with $\mathrm{Zn}(\mathrm{II})$ or cyanide ligand were investigated indicating an increase of the magnetic interaction between the spin carriers when compared to the open form. However, no single molecule magnet behavior has been detected in theses manganese dimers. During crystallization studies, a closed tweezers presenting a salphen ligand with one imine oxidized to amide was unexpectedly obtained and characterized by XRD in the solid state. An intramolecular bridge by the apical coordination of the so formed amido group to the second $\mathrm{Mn}$-salphen unit resulted in an antiferromagnetic coupling between the two $\mathrm{Mn}$ (III). To conclude, $\mathrm{Mn}$ (III) based molecular tweezers offer stimulating bridged closed conformation with dual stimulus that were not accessible in previous systems. Optimization of the tweezers considering $\mu$-oxo bridges or modified salphen ligands will be achieved in future work to exploit $\mathrm{Mn}$ (III) anisotropy and combine mechanical motion and SMM properties. 


\section{Experimental section}

General Analytical and Synthetic Methods. ${ }^{1} \mathrm{H}$ NMR and ${ }^{13} \mathrm{C}$ NMR spectra were recorded at 400 or $600 \mathrm{MHz}$ on Bruker Avance III spectrometers. Chemical shifts $(\delta)$ are reported in ppm from tetramethylsilane using residual solvent peaks for calibration. Electrospray ionisation (ESI) mass spectrometry was performed on a Bruker microTOF spectrometer. Reagent grade tetrahydrofuran was distilled from sodium and benzophenone. Tetrahydrofuran and triethylamine were degassed by three freeze-pump-thaw cycles before being used in the Sonogashira coupling reactions. Chloroform and methanol solvents were EPR grade. Chloroform was previously neutralized on $\mathrm{Al}_{2} \mathrm{O}_{3}$. All others chemicals were purchased from commercial suppliers and used without further purification. Flash column chromatography was performed using silica gel from Merck $(40-63 \mu \mathrm{m})$ or GraceResolv High Resolution Flash Cartridges (particle size $40 \mu \mathrm{m}$ ). Thin layer chromatography was performed using aluminium plates precoated with silica gel 60 F254 0.20 mm layer thickness purchased from VWR. Absorption spectra were recorded on a JASCO V-670 spectrophotometer.

Mn-Salphen 3. In a round bottom flask Salphen $2^{11 a}(1.2 \mathrm{~g}$, $1.94 \mathrm{mmol}, 1$ equiv) was dissolved in $\mathrm{CH}_{2} \mathrm{Cl}_{2}(20 \mathrm{~mL})$. After addition of $\mathrm{NEt}_{3}(0.78 \mathrm{~mL}, 588 \mathrm{mg}, 5.81 \mathrm{mmol}, 3$ equiv), a solution of $\mathrm{MnCl}_{2}, 4 \mathrm{H}_{2} \mathrm{O}$ (1.15 g, $5.81 \mathrm{mmol}, 3$ equiv) in $\mathrm{MeOH}$ $(20 \mathrm{~mL})$ was slowly added. The mixture was stirred at room temperature during $6 \mathrm{~h}$. Solvent was evaporated under reduced pressure and the crude product was purified by plug filtration $\left(\mathrm{SiO}_{2}: \mathrm{CH}_{2} \mathrm{Cl}_{2} / \mathrm{MeOH}(100 / 0 ; 95 / 5)\right.$ ). Complex 3 was isolated after evaporation of the filtrate obtained by elution with $95 / 5$ solvent ratio, in a yield of $98 \%$ (1.34 g). ESI-HRMS $\mathrm{m} / \mathrm{z}(\%):[\mathrm{M}-\mathrm{Cl}]^{+}$calc $\left(\mathrm{C}_{36} \mathrm{H}_{45} \mathrm{BrMnN}_{2} \mathrm{O}_{2}\right): 673.2021$ (100), found: 673.2017; Elemental analysis calc (\%) for $\mathrm{C}_{36} \mathrm{H}_{45} \mathrm{BrClMnN}_{2} \mathrm{O}_{2}$ : C 61.07, H 6.41, N 3.96; found: C 60.83, H 6.45, N 3.77.

Mn-Salphen 4. In a Schlenk tube under argon were introduced 3 (1.0 g, $1.41 \mathrm{mmol}, 1$ equiv), $\mathrm{PdCl}_{2}\left(\mathrm{PPh}_{3}\right)_{2}$ (148 mg, 0.212 $\mathrm{mmol}, 15 \mathrm{~mol} \%$ ), Cul (81 $\mathrm{mg}, 0.424 \mathrm{mmol}, 30 \mathrm{~mol} \%$ ). A mixture of $\mathrm{NEt}_{3}(10 \mathrm{~mL})$ and $\operatorname{THF}(20 \mathrm{~mL})$ previously distilled and degased was then added. The mixture was heated to $70^{\circ} \mathrm{C}$, and TMSA ( $2.00 \mathrm{~mL}, 1.39 \mathrm{~g}, 14.1 \mathrm{mmol}, 10$ equiv) was added. The mixture was heated under argon at $70^{\circ} \mathrm{C}$ for $15 \mathrm{~h}$. Solvent was evaporated under reduced pressure, and the crude product was purified by column chromatography $\left(\mathrm{SiO}_{2}\right.$ : Cyclohexane / $\mathrm{CH}_{2} \mathrm{Cl}_{2} / \mathrm{MeOH}(100 / 0 / 0)$ - (0/100/0) $(0 / 90 / 10)$ ) yielding pure product 4 as a brown solid $(59 \%, 603$ $\mathrm{mg})$. ESI-HRMS $\mathrm{m} / \mathrm{z}(\%)$ : $[\mathrm{M}-\mathrm{Cl}]^{+}$calc $\left(\mathrm{C}_{41} \mathrm{H}_{54} \mathrm{MnN}_{2} \mathrm{O}_{2} \mathrm{Si}\right)$ : 689.3330 (100), found: 689.3346 (100). Elemental analysis calc (\%) for $\left(\mathrm{C}_{41} \mathrm{H}_{54} \mathrm{ClMnN}_{2} \mathrm{O}_{2} \mathrm{Si}+2 \mathrm{CH}_{3} \mathrm{OH}\right): \mathrm{C} 65.42, \mathrm{H}$ 7.92, N 3.55; found: C 64.98, H 7.18, N 3.48 .

Salphen 6. In a Schlenk tube under argon were introduced 2 ( $2.0 \mathrm{~g}, 3.23 \mathrm{mmol}, 1$ equiv), $\mathrm{PdCl}_{2}\left(\mathrm{PPh}_{3}\right)_{2}(340 \mathrm{mg}, 0.485 \mathrm{mmol}$, $15 \mathrm{~mol} \%)$, Cul (185 mg, $0.970 \mathrm{mmol}, 30 \mathrm{~mol} \%)$. A mixture of $\mathrm{NEt}_{3}(10 \mathrm{~mL})$ and THF $(20 \mathrm{~mL})$ previously distilled and degased was then added. The mixture was heated at $70^{\circ} \mathrm{C}$, and TMSA (3.65 mL, $2.54 \mathrm{~g}, 25.8 \mathrm{mmol}, 8$ equiv) was added. The mixture was heated under argon at $70^{\circ} \mathrm{C}$ for $16 \mathrm{~h}$. Solvent was evaporated under reduced pressure, and the crude product was purified by column chromatography $\left(\mathrm{SiO}_{2}\right.$ : Cyclohexane / $\left.\mathrm{CH}_{2} \mathrm{Cl}_{2}(100 / 0)-(50 / 50)\right)$. After solvent evaporation, the product was recrystallized in $\mathrm{MeOH}$ yielding $56 \%$ (1.159 g) of product 6. ${ }^{1} \mathrm{H}$ NMR $\left(400 \mathrm{MHz}, \mathrm{CDCl}_{3}\right): \delta 13.39(\mathrm{~s}, 1 \mathrm{H}), 13.37(\mathrm{~s}$, $1 \mathrm{H}), 8.66(\mathrm{~s}, 1 \mathrm{H}), 8.65(\mathrm{~s}, 1 \mathrm{H}), 7.44(\mathrm{~d}, J=2.4 \mathrm{~Hz}, 2 \mathrm{H}), 7.41(\mathrm{dd}$, $J=8.2,1.8 \mathrm{~Hz}, 1 \mathrm{H}), 7.35(\mathrm{~d}, J=1.7 \mathrm{~Hz}, 1 \mathrm{H}), 7.22(\mathrm{~d}, J=2.5 \mathrm{~Hz}$, $1 \mathrm{H}), 7.20(\mathrm{~d}, J=2.4 \mathrm{~Hz}, 1 \mathrm{H}), 7.17(\mathrm{~d}, J=8.2 \mathrm{~Hz}, 1 \mathrm{H}), 1.43(\mathrm{~s}$, $18 \mathrm{H}), 1.32(\mathrm{~s}, 9 \mathrm{H}), 1.31(\mathrm{~s}, 9 \mathrm{H}), 0,28(\mathrm{~s}, 9 \mathrm{H}) ;{ }^{13} \mathrm{C} \mathrm{NMR}(101 \mathrm{MHz}$, $\left.\mathrm{CDCl}_{3}\right) \delta 165.30,165.07,158.81,158.76,143.07,142.81$, $140.60,140.57,140.53,137.42,137.38,131.00,128.65$, $128.58,127.08,127.04,123.27,122.15,119.92,118.44$, $104.43,95.52,35.27,34.33,31.61,29.58,0.13$; ESI-HRMS $m / z$ (\%): $[\mathrm{M}+\mathrm{Na}]^{+}$calc $\left(\mathrm{C}_{41} \mathrm{H}_{56} \mathrm{~N}_{2} \mathrm{O}_{2} \mathrm{SiNa}\right): 659.4003$ (100), found: 659.4027 (100); Elemental analysis calc (\%) for $\mathrm{C}_{41} \mathrm{H}_{56} \mathrm{~N}_{2} \mathrm{O}_{2} \mathrm{Si}$ : C 77.31, H 8.86, N 4.40; found: C 77.15, H 9.02, N 4.35.

Salphen 7. In a round bottom flask, $6(1.30 \mathrm{~g}, 2.04 \mathrm{mmol}, 1$ equiv) was dissolved in a mixture of THF $(10 \mathrm{~mL})$ and $\mathrm{MeOH}$ (10 mL) and $\mathrm{K}_{2} \mathrm{CO}_{3}$ (564 mg, $4.08 \mathrm{mmol}, 2$ equiv) was added. The mixture was stirred at room temperature during $3 \mathrm{~h}$. The solvent was evaporated under reduced pressure, and the yellow crude product was purified by plug filtration $\left(\mathrm{SiO}_{2}\right.$, $\mathrm{CH}_{2} \mathrm{Cl}_{2}$ ). After solvent evaporation, the solid was recrystallized from $\mathrm{MeOH}$. Pure product 7 was obtained after filtration and drying as an orange solid (714 mg, $81 \%) .{ }^{1} \mathrm{H}$ NMR $(400 \mathrm{MHz}$, $\left.\mathrm{CDCl}_{3}\right): \delta 13.36(\mathrm{~s}, 1 \mathrm{H}), 13.33(\mathrm{~s}, 1 \mathrm{H}), 8.66(\mathrm{~s}, 1 \mathrm{H}), 8.65(\mathrm{~s}, 1 \mathrm{H})$, 7.45 (d, $J=2.4 \mathrm{~Hz}, 2 \mathrm{H}$ ), 7.43 (dd, $J=8.2 \mathrm{~Hz}, 1.8 \mathrm{~Hz}, 1 \mathrm{H}$ ), 7.37 (d, $J=1.8 \mathrm{~Hz}, 1 \mathrm{H}), 7.24-7.16(\mathrm{~m}, 3 \mathrm{H}), 3.15(\mathrm{~s}, 1 \mathrm{H}), 1.43(\mathrm{~s}, 18 \mathrm{H})$, $1.32(\mathrm{~s}, 18 \mathrm{H}) ;{ }^{13} \mathrm{C}$ NMR $\left(101 \mathrm{MHz}, \mathrm{CDCl}_{3}\right) \delta 165.47,165.25$, $158.82,158.75,143.37,142.95,140.64,137.45,137.41$, $131.09,128.73,128.67,127.10,127.06,123.54,121.07$, $120.04,118.42,83.11,78.26,35.28,34.32,31.60,29.58$; ESIHRMS $m / z$ (\%): $[\mathrm{M}+\mathrm{Na}]^{+}$calc $\left(\mathrm{C}_{38} \mathrm{H}_{48} \mathrm{~N}_{2} \mathrm{O}_{2} \mathrm{Na}\right): 587.3608$ (100), found: 587.3619 (100)

Mn-Salphen 5. In a round bottom flask compound 7 (530 mg, 0.938 mmol, 1 equiv) was dissolved in $\mathrm{CH}_{2} \mathrm{Cl}_{2}$ (15 mL). After addition of $\mathrm{NEt}_{3}(0.38 \mathrm{~mL}, 285 \mathrm{mg}, 2.81 \mathrm{mmol}, 3$ equiv), a solution of $\mathrm{MnCl}_{2}, 4 \mathrm{H}_{2} \mathrm{O}$ (223 mg, $1.13 \mathrm{mmol}, 1.2$ equiv) in $\mathrm{MeOH}(15 \mathrm{~mL})$ was slowly added. The mixture was stirred at room temperature during $3 \mathrm{~h}$. Solvent was evaporated under reduced pressure, the crude product was purified by plug filtration $\left(\mathrm{SiO}_{2}: \mathrm{CH}_{2} \mathrm{Cl}_{2} / \mathrm{MeOH}(100 / 0 ; 95 / 5)\right)$. Product 5 (71\%, $437 \mathrm{mg}$ ) was isolated after evaporation of the filtrate obtained by elution with $95 / 5$ solvent ratio. ESI-HRMS $\mathrm{m} / \mathrm{z}(\%)$ : $[\mathrm{M}-\mathrm{Cl}]^{+}$ calc $\left(\mathrm{C}_{38} \mathrm{H}_{46} \mathrm{MnN}_{2} \mathrm{O}_{2}\right)$ : 617.2934 (100), found: 617.2950 (100); Elemental analysis calc (\%) for $\left(\mathrm{C}_{38} \mathrm{H}_{46} \mathrm{ClMnN}_{2} \mathrm{O}_{2}+\mathrm{CH}_{3} \mathrm{OH}\right)$ : C 68.36, H 7.36, N 4.09; found: C 68.97, H 7.14, N 4.11.

Tweezers ligand 9. In a Schlenk tube under argon 6,6"Dibromo-2,2':6',2"'-terpyridine 8 (35 mg, $0.089 \mathrm{mmol}, 1$ equiv), Salphen 7 (200 mg, $0.354 \mathrm{mmol}, 4$ equiv), $\mathrm{PdCl}_{2}\left(\mathrm{PPh}_{3}\right)_{2}(9 \mathrm{mg}$, $0.013 \mathrm{mmol}, 15 \mathrm{~mol} \%$ ) and Cul (2.5 mg, $0.013 \mathrm{mmol}, 15 \mathrm{~mol} \%)$ were introduced. A mixture of $\operatorname{NEt}_{3}(3 \mathrm{~mL})$ / THF $(6 \mathrm{~mL})$ previously distilled and degased by freeze pump thaw was then added. The mixture was heated at $70^{\circ} \mathrm{C}$ under argon during $15 \mathrm{~h}$. After solvent evaporation, the crude product was purified by column chromatography $\left(\mathrm{SiO}_{2}\right.$ : Cyclohexane / $\mathrm{CH}_{2} \mathrm{Cl}_{2}$ / AcOEt (100/0/0)-(0/100/0)-(0/50/50)), then 
recrystallized from EtOH yielding 9 as an orange solid $(44 \mathrm{mg}$, $51 \%) .{ }^{1} \mathrm{H}$ NMR $\left(400 \mathrm{MHz}, \mathrm{CDCl}_{3}\right): \delta 13.39(\mathrm{~s}, 2 \mathrm{H}), 13.36(\mathrm{~s}, 2 \mathrm{H})$, $8.73(\mathrm{~s}, 2 \mathrm{H}), 8.70(\mathrm{~s}, 2 \mathrm{H}), 8.61(\mathrm{dd}, J=8.1,1.1 \mathrm{~Hz}, 2 \mathrm{H}), 8.60(\mathrm{~d}, J$ $=7.9 \mathrm{~Hz}, 2 \mathrm{H}), 8.00(\mathrm{t}, J=7.8 \mathrm{~Hz}, 1 \mathrm{H}), 7.89(\mathrm{t}, J=7.8 \mathrm{~Hz}, 2 \mathrm{H})$, $7.63-7.59(\mathrm{~m}, 4 \mathrm{H}), 7.55(\mathrm{~d}, J=1.7 \mathrm{~Hz}, 2 \mathrm{H}), 7.47(\mathrm{~d}, J=2.4 \mathrm{~Hz}$, $4 \mathrm{H}), 7.28-7.23(\mathrm{~m}, 6 \mathrm{H}), 1.44(\mathrm{~s}, 36 \mathrm{H}), 1.34(\mathrm{~s}, 18 \mathrm{H}), 1.33(\mathrm{~s}$, $18 \mathrm{H}) ;{ }^{13} \mathrm{C}$ NMR $\left(101 \mathrm{MHz}, \mathrm{CDCl}_{3}\right) \delta 165.52,165.25,158.88$ $158.78,156.86,154.87,143.53,143.08,142.84,140.67$ $138.13,137.47,137.43,137.20,131.08,128.78,128.70$, $127.51,127.15,127.09,123.50,122.00,121.33,120.68$, $120.18,118.46,90.10,88.48,35.30,34.34,31.61,29.59$; ESIHRMS $\mathrm{m} / \mathrm{z}$ (\%): $[\mathrm{M}+\mathrm{Na}]^{+}$calc $\left(\mathrm{C}_{91} \mathrm{H}_{103} \mathrm{~N}_{7} \mathrm{O}_{4} \mathrm{Na}\right): 1381.7997$ (100), found: 1381.7984 (100).

Tweezers $1-\mathrm{Cl}_{2}$. In a round bottom flask $10(30 \mathrm{mg}, 0.049$ mmol, 1 equiv) was dissolved in $\mathrm{CH}_{2} \mathrm{Cl}_{2}(20 \mathrm{~mL})$. After addition of $\mathrm{NEt}_{3}$ (78 $\mu \mathrm{L}, 60 \mathrm{mg}, 0.58 \mathrm{mmol}, 12$ equiv), a solution of $\mathrm{MnCl}_{2}, 4 \mathrm{H}_{2} \mathrm{O}$ (58 mg, $0.292 \mathrm{mmol}, 6$ equiv) in $\mathrm{MeOH}(15 \mathrm{~mL}$ ) was slowly added. The mixture was stirred at room temperature during $4 \mathrm{~h}$. After solvent evaporation under reduced pressure, $\mathrm{CH}_{2} \mathrm{Cl}_{2}$ and 10 drops of $N, N, N^{\prime}, N^{\prime \prime}, N^{\prime \prime}$ Pentamethyldiethylenetriamine. The organic layer was then washed with water and evaporated. A final recrystallization in acetonitrile yielded tweezers $1-\mathrm{Cl}_{2}$ as a brown solid $(22 \mathrm{mg}, 65$ \%). ESI-HRMS $\mathrm{m} / \mathrm{z}(\%)$ : $[\mathrm{M}-2 \mathrm{Cl}]^{2+}$ calc $\left(\mathrm{C}_{91} \mathrm{H}_{99} \mathrm{Mn}_{2} \mathrm{~N}_{7} \mathrm{O}_{4}\right)$ : 731.8254 (100), found: 731.8392 (100); [M - Cl] ${ }^{+}$calc $\left(\mathrm{C}_{91} \mathrm{H}_{99} \mathrm{ClMn}_{2} \mathrm{~N}_{7} \mathrm{O}_{4}\right): 1499.6242$ (100), found: 1499.6203 (100). Elemental analysis calc (\%) for $\left(\mathrm{C}_{91} \mathrm{H}_{99} \mathrm{Cl}_{2} \mathrm{Mn}_{2} \mathrm{~N}_{7} \mathrm{O}_{4}+\mathrm{H}_{2} \mathrm{O}\right) \mathrm{C}$ 70.72, H 6.55, N 6.31; found: C 70.81, H 6.51, N 6.45.

Mn-Salphen 10: In a round bottom flask N,N'-Bis(3,5-di-tertbutylsalicylidene)-1,2-phenylenediamine ${ }^{31}(80 \mathrm{mg}, 0.15 \mathrm{mmol}$, 1 equiv) was dissolved in $\mathrm{CH}_{2} \mathrm{Cl}_{2}(5 \mathrm{~mL})$. After addition of 3 drops of $\mathrm{NEt}_{3}$, a solution of $\mathrm{MnCl}_{2}, 4 \mathrm{H}_{2} \mathrm{O}(87 \mathrm{mg}, 0.44 \mathrm{mmol}, 3$ equiv) in $\mathrm{MeOH}(5 \mathrm{~mL}$ ) was slowly added. The mixture was stirred at room temperature during $6 \mathrm{~h}$. Solvent was evaporated under reduced pressure. The final product was obtained by precipitation in acetonitrile as a brown solid (59 $\mathrm{mg}, 67 \%)$. ESI-HRMS $\mathrm{m} / \mathrm{z}(\%)$ : $[\mathrm{M}-\mathrm{Cl}]^{+}$calc $\left(\mathrm{C}_{36} \mathrm{H}_{46} \mathrm{MnN}_{2} \mathrm{O}_{2}\right)$ : 593.2940 (100), found: 593.2945 (100); Elemental analysis calc (\%) for $\left(\mathrm{C}_{36} \mathrm{H}_{46} \mathrm{ClMnN}_{2} \mathrm{O}_{2}+\mathrm{H}_{2} \mathrm{O}\right) \mathrm{C} 66.81, \mathrm{H} 7.48, \mathrm{~N}$ 4.33; found: C 66.64, H 7.39, N 4.25.

Crystal data for $\left[\mathrm{Zn}\left(1-\mathrm{Cl}_{2}\right)\right] \mathrm{Cl}_{2}$. Single crystals were grown by slow evaporation of a solution of $\left[\mathrm{Zn}\left(1-\mathrm{Cl}_{2}\right)\right] \mathrm{Cl}_{2}$ in $\mathrm{MeOH}$. Brown plates-like crystals were obtained: $\mathrm{C}_{98} \mathrm{H}_{129} \mathrm{Cl}_{4} \mathrm{Mn}_{2} \mathrm{~N}_{7} \mathrm{O}_{12} \mathrm{Zn}$, triclinic, P-1, $a=14.1647(2), b=$ $15.3020(2), c=25.9901$ (4) $\AA, \alpha=88.1420(10), \beta=84.2230(10)$, $\gamma=66.4380(10)^{\circ}, V=5137.24(13) \AA^{3}, Z=2, T=100(2) \mathrm{K} .34853$ reflections measured, 25877 observed $[I \geq 2 \sigma(I)], 1246$ parameters, final $R$ indices $R_{1}[I \geq 2 \sigma(I)]=0.0654$ and $w R_{2}$ (all data $)=0.2087, \mathrm{GOF}=1.043$.

Crystal data for oxidized tweezers: Single crystals were grown by slow evaporation of a solution $\left[\mathrm{Zn}\left(1-\mathrm{Cl}_{2}\right)\right] \mathrm{Cl}_{2}$ in presence of TBACN (2 eq) in $\mathrm{MeOH}$. Brown crystals were obtained: $\mathrm{C}_{194} \mathrm{H}_{240} \mathrm{Cl}_{4} \mathrm{Mn}_{4} \mathrm{~N}_{17} \mathrm{O}_{27} \mathrm{Zn}_{3}$, triclinic, $\mathrm{P}-1, a=15.1358(12), b=$ 16.5212(10), $c=22.9401(16) \AA, \alpha=89.629(5), \beta=72.981(5), \gamma$ $=73.972(5)^{\circ}, \mathrm{V}=\AA^{3}, \mathrm{Z}=1, \mathrm{~T}=200(2) \mathrm{K} .18995$ reflections measured, 6549 observed $[I \geq 2 \sigma(I)], 1123$ parameters, final $R$ indices $R_{1}[I \geq 2 \sigma(I)]=0.0843$ and $w R_{2}$ (all data $)=0.2657$, GOF $=$ 1.047 .

A single crystal of $\left[\mathrm{Zn}\left(\mathbf{1}-\mathrm{Cl}_{\mathbf{2}}\right)\right] \mathrm{Cl}_{2}$ was selected in a drop of glue, mounted onto a glass fiber, and transferred in a cold nitrogen gas stream. The data collection for $[\mathrm{Zn}(\mathbf{1})] \mathrm{Cl}_{2}$ was carried out on the 4-circle diffractometer at the CRISTAL beamline (SOLEIL synchrotron, Paris) using the synchrotron radiation source $(\lambda=$ $0.66825 \AA$ ) up to a maximum resolution of $0.8 \AA^{-1}$, reaching 97 $\%$ of completeness. Data collection strategies were generated with the CrysAlisPro CCD package. Unit-cell parameters refinement, data reduction, scaling and absorption correction were carried out with CrysAlisPro. The sample was treated as a two domains twin for data reduction. In the WinGX suite of programs, $^{32}$ the structure was solved with SHELXS-97 program $^{33}$ and refined by full-matrix least-squares methods using SHELXL-2013 and a HKLF5 type hkl file. All non-hydrogen atoms were refined anisotropically while one acetonitrile solvent molecule was refined isotropically. Hydrogen atoms were placed at calculated positions. Geometrical restraints were introduced for t-butyl groups and solvent molecules. Restraints on ADP's were also used for the latter parts of the structure.

A single crystal of the oxidized tweezers was mounted onto a cryoloop, and transferred in a cold nitrogen gas stream. Intensity data were collected with a BRUKER Kappa-APEXII diffractometer with graphite-monochromated Mo-K $\alpha$ radiation $(\lambda=0.71073 \AA$ A ). Data collection was performed with APEX2 suite (BRUKER). Unit-cell parameters refinement, integration and data reduction were carried out with SAINT program (BRUKER). SADABS (BRUKER) was used for scaling and multi-scan absorption corrections. Similarly, WinGX and the SHELXS/L softwares were used for structure solution and refinement.

CCDC 1846793, 1846794 contain the supplementary crystallographic data for this paper. These data can be obtained free of charge from The Cambridge Crystallographic Data Centre via www.ccdc.cam.ac.uk/data_request/cif.

UV-Vis Titrations: UV-Vis titrations were performed on $3.0 \mathrm{~mL}$ of open tweezers $\left(5.0 \times 10^{-6} \mathrm{M}\right.$ ) dissolved in $\mathrm{CHCl}_{3}$ (previously neutralized on $\left.\mathrm{Al}_{2} \mathrm{O}_{3}\right)$ in a quartz cell $(10 \mathrm{~mm})$, were added 0.2 eq $\left(3 \mu \mathrm{L}\right.$ of solution $1.0 \times 10^{-3} \mathrm{M}$ ) of $\mathrm{ZnCl}_{2}$ dissolved in $\mathrm{CH}_{3} \mathrm{CN}$. After each addition, a UV-Visible absorption spectrum (250 $700 \mathrm{~nm}, 400 \mathrm{~nm} / \mathrm{min}, 25^{\circ} \mathrm{C}$ ) was recorded immediately and after 5 minutes to check that the equilibrium was reached. Binding constants were obtained by a nonlinear least-squares fit of the absorbance versus the concentration of guest added using the Matlab program developed by P. Thordarson. ${ }^{34}$

EPR experiment: EPR experiments were performed on $150 \mu \mathrm{L}$ of open tweezers $\left(1.0 \times 10^{-4} \mathrm{M}\right)$ dissolved in $\mathrm{MeOH}$ in a quartz tube $(4 \mathrm{~mm})$. To the open form $\mathrm{ZnCl}_{2}$ dissolved in $\mathrm{MeOH}(1.0 \times$ $\left.10^{-1} \mathrm{M}\right)$ was added. To the open/closed form was added a solution of TBACN dissolved in $\mathrm{MeOH}\left(5.0 \times 10^{-2} \mathrm{M}\right)$.

SQUID experiment: Liquid squid experiment were performed on $200 \mu \mathrm{L}$ of open tweezers $\left(1.30 \times 10^{-3} \mathrm{M}\right)$ dissolved in chloroform (previously neutralized on $\mathrm{Al}_{2} \mathrm{O}_{3}$ ) in a quartz tube with a Quantum Design MPMS-XL SQUID magnetometer. 1 equiv of a solution of $\mathrm{ZnCl}_{2}$ in $\mathrm{MeCN}$ was added (0.1). A 
solution of TBACN was prepared in $\operatorname{MeCN}\left(5 \times 10^{-2} \mathrm{M}\right)$ and 1.2 equivalents were added.

\section{Acknowledgements}

B.D. thanks the Ecole Normale Supérieure of Cachan for a PhD Fellowship. We are grateful to Dr. P. Fertey (CRISTAL beamline team, synchrotron SOLEIL) and Dr. S. Pillet (CRM2, Nancy) for their kind help in the collection of SC-XRD data. This work benefited from the support of the French National Research Agency (ANR) for the project JCJC SMARTEES (15-CE07-000601).

\section{Conflicts of interest}

There are no conflicts to declare.

\section{Notes and references}

1. a) V. Balzani, M. Venturi and A. Credi, Molecular Devices and Machines: Concepts and Perspectives for the Nanoworld, WileyVCH: Weinheim, 2008; b) S. Erbas-Cakmak, D. A. Leigh, C. T. McTernan and A. L. Nussbaumer, Chem. Rev., 2015, 115, 1008110206.

2. E. R. Kay and D. A. Leigh, Angew. Chem. Int. Ed., 2015, 54, 10080-10088.

3. a) B. L. Feringa, Molecular Switches, Wiley $-\mathrm{VCH}$, Weinheim, 2001; b) F. Puntoriero, F. Nastasi, T. Bura, R. Ziessel, S. Campagna and A. Giannetto, New J. Chem., 2011, 35, 948-952; c) T. Gunnlaugsson and J. P. Leonard, Chem. Commun., 2005, 31143131; d) X. Su and I. Aprahamian, Chem. Soc. Rev., 2014, 43, 1963-1981; e) M. Schmittel, Chem. Commun., 2015, 51, 1495614968; f) G. Sudhakar, G. Abir, D. Soumen and S. Michael, Angew. Chem. Int. Ed., 2016, 55, 10512-10517; g) N. Mittal, S. Pramanik, I. Paul, S. De and M. Schmittel, J. Am. Chem. Soc., 2017, 139, 4270-4273; h) A. J. McConnell, C. S. Wood, P. P. Neelakandan and J. R. Nitschke, Chem. Rev., 2015, 115, 77297793; i) S. Lamsaard, S. J. Asshoff, B. Matt, T. Kudernac, J. L. M. Cornelissen, S. P. Fletcher and N. Katsonis, Nat Chem, 2014, 6, 229-235.

4. a) N. Armaroli, V. Balzani, J. P. Collin, P. Gavina, J. P. Sauvage and B. Ventura, J. Am. Chem. Soc., 1999, 121, 4397-4408; b) A. M. Brouwer, C. Frochot, F. G. Gatti, D. A. Leigh, L. Mottier, F. Paolucci, S. Roffia and G. W. H. Wurpel, Science, 2001, 291, 2124-2128.

5. a) T. R. Kelly, H. De Silva and R. A. Silva, Nature, 1999, 401, 150-152; b) N. Koumura, R. W. J. Zijistra, R. A. Van Delden, N. Harada and B. L. Feringa, Nature, 1999, 401, 152-155; c) D. A. Leigh, J. K. Y. Wong, F. Dehez and F. Zerbetto, Nature, 2003, 424, 174-179; d) R. A. van Delden, M. K. J. ter Wiel, M. M. Pollard, J. Vicario, N. Koumura and B. L. Feringa, Nature, 2005, 437, 13371340; e) V. Balzani, M. Clemente-Leon, A. Credi, B. Ferrer, M. Venturi, A. H. Flood and J. F. Stoddart, Proc. Natl. Acad. Sci. U. S. A., 2006, 103, 1178-1183; f) G. Vives, H. P. J. de Rouville, A. Carella, J. P. Launay and G. Rapenne, Chem. Soc. Rev., 2009, 38, 1551-1561; g) U. G. E. Perera, F. Ample, H. Kersell, Y. Zhang, G. Vives, J. Echeverria, M. Grisolia, G. Rapenne, C. Joachim and S. W. Hla, Nature Nanotech., 2013, 8, 46-51; h) M. R. Wilson, J. Sol, A. Carlone, S. M. Goldup, N. Lebrasseur and D. A. Leigh, Nature, 2016, 534, 235.

6. a) Y. Shirai, J.-F. Morin, T. Sasaki, J. M. Guerrero and J. M. Tour, Chem. Soc. Rev., 2006, 35, 1043-1055; b) G. Vives and J. M. Tour, Acc. Chem. Res., 2009, 42, 473-487; c) T. Kudernac, N.
Ruangsupapichat, M. Parschau, B. Macia, N. Katsonis, S. R. Harutyunyan, K. H. Ernst and B. L. Feringa, Nature, 2011, 479, 208-211.

7. a) C. W. Chen and H. W. Whitlock, J. Am. Chem. Soc., 1978, 100, 4921-4922; b) J. Leblond and A. Petitjean, ChemPhysChem, 2011, 12, 1043-1051; c) M. Hardouin-Lerouge, P. Hudhomme and M. Salle, Chem. Soc. Rev., 2011, 40, 30-43; d) F.-G. Klärner and B. Kahlert, Acc. Chem. Res., 2003, 36, 919-932; e) S. Zimmerman, Top. Curr. Chem., 1993, 165, 71-102.

8. a) M. Skibinski, R. Gomez, E. Lork and V. A. Azov, Tetrahedron, 2009, 65, 10348-10354; b) A. lordache, M. Retegan, F. Thomas, G. Royal, E. Saint-Aman and C. Bucher, Chem. Eur. J., 2012, 18, 7648-7653.

9. a) S. Shinkai, T. Nakaji, T. Ogawa, K. Shigematsu and O. Manabe, J. Am. Chem. Soc., 1981, 103, 111-115; b) T. Muraoka, K. Kinbara, Y. Kobayashi and T. Aida, J. Am. Chem. Soc., 2003, 125, 5612-5613.

10. a) M. Barboiu, L. Prodi, M. Montalti, N. Zaccheroni, N. Kyritsakas and J.-M. Lehn, Chem. Eur. J., 2004, 10, 2953-2959; b) A. Petitjean, R. Khoury, N. Kyritsakas and J.-M. Lehn, J. Am. Chem. Soc., 2004, 126, 6637-6647; c) M. Linke-Schaetzel, C. E. Anson, A. K. Powell, G. Buth, E. Palomares, J. D. Durrant, T. S. Balaban and J. M. Lehn, Chem. Eur. J., 2006, 12, 1931-1940; d) M. Barboiu, Y.-M. Legrand, L. Prodi, M. Montalti, N. Zaccheroni, G. Vaughan, A. van der Lee, E. Petit and J.-M. Lehn, Eur. J. Inorg. Chem., 2009, 2009, 2621-2628; e) S. Ulrich and J.-M. Lehn, Chem. Eur. J., 2009, 15, 5640-5645; f) S. Ulrich, A. Petitjean and J.-M. Lehn, Eur. J. Inorg. Chem., 2010, 2010, 1913-1928; g) J. Leblond, H. Gao, A. Petitjean and J.-C. Leroux, J. Am. Chem. Soc., 2010, 132, 8544-8545; h) X. Su, S. Voskian, R. P. Hughes and I. Aprahamian, Angew. Chem. Int. Ed., 2013, 52, 10734-10739; i) Y. Tsuchido, Y. Suzaki, T. Ide and K. Osakada, Chem. Eur. J., 2014, 20, 4762-4771.

11. a) B. Doistau, A. Tron, S. A. Denisov, G. Jonusauskas, N. D. McClenaghan, G. Gontard, V. Marvaud, B. Hasenknopf and G. Vives, Chem. Eur. J., 2014, 20, 15799-15807; b) B. Doistau, C. Rossi-Gendron, A. Tron, N. D. McClenaghan, L.-M. Chamoreau, B. Hasenknopf and G. Vives, Dalton Trans., 2015, 44, 8543-8551; c) L. Benda, B. Doistau, B. Hasenknopf and G. Vives, Molecules, 2018, 23, 990.

12. B. Doistau, L. Benda, J.-L. Cantin, L.-M. Chamoreau, E. Ruiz, V. Marvaud, B. Hasenknopf and G. Vives, J. Am. Chem. Soc., 2017, 139, 9213-9220.

13. L. Benda, B. Doistau, C. Rossi-Gendron, L.-M. Chamoreau, B. Hasenknopf and G. Vives, Commun. Chem., 2019, 2, 144.

14. B. Doistau, J.-L. Cantin, L.-M. Chamoreau, V. Marvaud, B. Hasenknopf and G. Vives, Chem. Commun., 2015, 51, 1291612919.

15. a) B. Doistau, L. Benda, B. Hasenknopf, V. Marvaud and G. Vives, Magnetochemistry, 2018, 4, 5; b) S. Venkataramani, U. Jana, M. Dommaschk, F. D. Sönnichsen, F. Tuczek and R. Herges, Science, 2011, 331, 445-448; c) J. Wang, L. Hou, W. R. Browne and B. L. Feringa, J. Am. Chem. Soc., 2011, 133, 8162-8164; d) A. Fetoh, G. Cosquer, M. Morimoto, M. Irie, O. El-Gammal, G. A. ElReash, B. K. Breedlove and M. Yamashita, Sci. Rep., 2016, 6, 23785; e) V. Bleve, C. Schäfer, P. Franchi, S. Silvi, E. Mezzina, A. Credi and M. Lucarini, ChemistryOpen, 2015, 4, 18-21.

16. M. Hirotsu, N. Ohno, T. Nakajima, C. Kushibe, K. Ueno and I. Kinoshita, Dalton Trans., 2010, 39, 139-148.

17. J. F. Larrow, E. N. Jacobsen, Y. Gao, Y. Hong, X. Nie and C. M. Zepp, J. Org. Chem., 1994, 59, 1939-1942.

18. a) J. Y. Yang, S.-Y. Liu, I. V. Korendovych, E. V. Rybak-Akimova and D. G. Nocera, ChemSusChem, 2008, 1, 941-949; b) S.-Y. Liu and D. G. Nocera, J. Am. Chem. Soc., 2005, 127, 5278-5279.

19. a) N. Matsumoto, Y. Sunatsuki, H. Miyasaka, Y. Hashimoto, D. Luneau and J.-P. Tuchagues, Angew. Chem. Int. Ed., 1999, 38, 171-173; b) H. Hiraga, H. Miyasaka, R. Clérac, M. Fourmigué and M. Yamashita, Inorg. Chem., 2009, 48, 2887-2898; c) T. Glaser, 
Chem. Commun., 2011, 47, 116-130; d) H. Miyasaka, A. Saitoh and S. Abe, Coord. Chem. Rev., 2007, 251, 2622-2664.

20. K. S. Pedersen, J. Bendix and R. Clerac, Chem. Commun., 2014, 50, 4396-4415.

21. a) R. Sessoli, D. Gatteschi, A. Caneschi and M. A. Novak, Nature, 1993, 365, 141; b) R. Sessoli, H. L. Tsai, A. R. Schake, S. Wang, J. B. Vincent, K. Folting, D. Gatteschi, G. Christou and D. N. Hendrickson, J. Am. Chem. Soc., 1993, 115, 1804-1816; c) R. Bagai and G. Christou, Chem. Soc. Rev., 2009, 38, 1011-1026.

22. a) C. J. Milios, A. Vinslava, W. Wernsdorfer, S. Moggach, S. Parsons, S. P. Perlepes, G. Christou and E. K. Brechin, J. Am. Chem. Soc., 2007, 129, 2754-2755; b) C. J. Milios, R. Inglis, A Vinslava, R. Bagai, W. Wernsdorfer, S. Parsons, S. P. Perlepes, G. Christou and E. K. Brechin, J. Am. Chem. Soc., 2007, 129, 1250512511.

23. a) M. Hitoshi, C. Rodolphe, W. Wolfgang, L. Lollita, B. Claire, S. Ken-ichi and Y. Masahiro, Angew. Chem. Int. Ed., 2004, 43, 2801-2805; b) Z. Lü, M. Yuan, F. Pan, S. Gao, D. Zhang and D. Zhu, Inorg. Chem., 2006, 45, 3538-3548; c) L. Lecren, W. Wernsdorfer, Y.-G. Li, A. Vindigni, H. Miyasaka and R. Clérac, J. Am. Chem. Soc., 2007, 129, 5045-5051; d) C. Kachi-Terajima, R. Ishii, Y. Tojo, M. Fukuda, Y. Kitagawa, M. Asaoka and H. Miyasaka, J. Phys. Chem. C, 2017, 121, 12454-12468; e) D. Pinkowicz, H. I. Southerland, C. Avendaño, A. Prosvirin, C. Sanders, W. Wernsdorfer, K. S. Pedersen, J. Dreiser, R. Clérac, J. Nehrkorn, G. G. Simeoni, A. Schnegg, K. Holldack and K. R. Dunbar, J. Am. Chem. Soc., 2015, 137, 14406-14422.

24. Jay D. Pike, Dell T. Rosa and D. Coucouvanis, Eur. J. Inorg. Chem., 2001, 2001, 761-777

25. M. R. Netherton and G. C. Fu, Org. Lett., 2001, 3, 4295-4298.

26. W. Adam, C. Mock-Knoblauch, C. R. Saha-Möller and M. Herderich, J. Am. Chem. Soc., 2000, 122, 9685-9691.

27. a) K. A. Campbell, E. Yikilmaz, C. V. Grant, W. Gregor, A.-F. Miller and R. D. Britt, J. Am. Chem. Soc., 1999, 121, 4714-4715 b) K. A. Campbell, M. R. Lashley, J. K. Wyatt, M. H. Nantz and R. D. Britt, J. Am. Chem. Soc., 2001, 123, 5710-5719.

28. T. Kurahashi, Inorg. Chem., 2018, 57, 1066-1078.

29. a) S. F. A. Kettle, E. Diana, E. Boccaleri and P. L. Stanghellini, Inorg. Chem., 2007, 46, 2409-2416; b) K. Nakamoto, in Infrared and Raman Spectra of Inorganic and Coordination Compounds., John Wiley \& Sons, Inc, New York, 1997, vol. B. 5th ed; c) K. R. Dunbar and R. A. Heintz, Prog. Inorg. Chem., 1997, 45, 283-391.

30. E. Gallo, E. Solari, C. Floriani, N. Re, A. Chiesi-Villa and C. Rizzoli, Angew. Chem. Int. Ed., 1996, 35, 1981-1983.

31. C. F. Works, C. J. Jocher, G. D. Bart, X. Bu and P. C. Ford Inorg. Chem., 2002, 41, 3728-3739.

32. L. Farrugia, J. Appl. Crystallogr., 1999, 32, 837-838.

33. G. Sheldrick, Acta Crystallogr., Sect. A, 2008, 64, 112-122.

34. P. Thordarson, Chem. Soc. Rev., 2011, 40, 1305-1323. 